\title{
Effects of Magnesia and Potassium Sulfate on Gypsum-bonded Alumina Dental Investment for High-fusing Casting
}

\author{
Min YAN and Hidekazu TAKAHASHI \\ Department of Dental Technology I, Faculty of Dentistry, \\ Tokyo Medical and Dental University \\ 1-5-45 Yushima, Bunkyo-ku, Tokyo 113-8549, Japan
}

Received July 15, 1998/Accepted October 2, 1998

\begin{abstract}
The purpose of this study was to improve the characteristics of gypsum-bonded alumina investments using magnesia and potassium sulfate as chemical additives. Magnesia content improved fluidity, delayed setting reaction, increased green strength, and decreased setting expansion, when mixed with distilled water. When the investment was mixed with potassium sulfate, the setting time and setting expansion were reduced, and the thermal expansion increased, however, the green strength decreased. Therefore, the investment with a small amount of magnesia mixed with potassium sulfate was considered a suitable composition, having adequate setting behavior, enough green strength and sufficient compensate expansion for casting.
\end{abstract}

Key words: Gypsum-bonded investment, Investment for high-fusing alloy, Alumina

\section{INTRODUCTION}

Gypsum-bonded investments are considered unsuitable for high-fusing alloy casting because of the decomposition of gypsum at high temperatures ${ }^{1)}$. However, it has been reported that a mixture of gypsum and alumina shows high expansion because of the reaction of alumina and calcia decomposed from gypsum ${ }^{2}$. In previous papers ${ }^{3)}$, we developed an experimental gypsum-bonded alumina investment for high-fusing alloys, and its characteristics were investigated; 20 or 25 mass\% gypsum content gave the fundamental properties for high-fusing alloy casting. However, a few problems regarding setting time of these investments were found.

It is well known that chemical additives have an influence on the characteristics of a gypsum product. Magnesia is one stable refractory at a high temperature ${ }^{4)}$ and forms the oxide compound spinel with alumina at $900-1200^{\circ} \mathrm{C}^{5)}$. Potassium sulfate functions as an accelerator for gypsum and controls the setting expansion ${ }^{1,6)}$. In this study, magnesia and potassium sulfate were selected as chemical additives for a gypsum-bonded investment. The effects of these additives on the investment were investigated in an effort to improve the characteristics of the investment, and casting of titanium using this investment was evaluated. 


\section{MATERIALS AND METHODS}

\section{Experimental investment}

According to our previous study ${ }^{3)}$ a calcium sulfate hemihydrate without an additive, essentially identical to a dental stone used for a commercial gypsum-bonded investment (Cristobalite Micro, GC, Tokyo, Japan) was selected as a binder and added at $20 \mathrm{mass} \%$ to the refractory material.

Alumina powder (Fuji-random wa-220, Fujiseisaku, Tokyo, Japan) was selected because investments of this powder show relatively small setting expansion and a large thermal expansion. Electrically fused magnesia powder ( $\mathrm{MgO}$; RA-F, Tateho Kagaku, Hyogo, Japan) was selected as an additive for the alumina powder. The chemical compositions of the alumina and magnesia powders supplied are listed in Table 1. Five kinds of experimental gypsum-bonded investments were prepared; their magnesia contents were $0.0,6.1,11.7,16.3$, and 28.7 mass\% (Table 2).

The investment was mixed with distilled water or 2 mass $\%$ potassium sulfate $\left(\mathrm{K}_{2} \mathrm{SO}_{4}\right.$; Grade $\mathrm{S}$, Wako Chemical Industries, Osaka, Japan) solution at a water/powder ratio of 0.28 by hand for 30 seconds and another 30 seconds with a vacuum mixing machine (Vac-U-Mixer, Whip-Mix, Fort Wayns, IN, USA). As the investments containing more than 16.3 mass\% $\mathrm{MgO}$ mixed with distilled water did not set until 120 minutes after the start of mixing, the only the fluidity investments were taken.

\section{Fluidity}

Fluidity was measured using the slump test JIS T6601 ${ }^{7)}$ for a gypsum-bonded investment. The freshly mixed investment was poured into a brass ring $(28 \mathrm{~mm}$ in diameter and $50 \mathrm{~mm}$ in length) on a glass slab, then the brass ring was pulled up 2 minutes after the start of mixing. Fluidity was determined as the mean of the maximum and the minimum diameter of the slurry 3 minutes after the start of mixing. Three measurements were performed for each investment.

Table 1 Chemical composition of alumina and magnesia powder

\begin{tabular}{ccccccccc}
\hline \multirow{2}{*}{$\begin{array}{c}\text { Refractory } \\
\text { material }\end{array}$} & $\mathrm{Al}_{2} \mathrm{O}_{3}$ & $\mathrm{MgO}$ & $\mathrm{TiO}_{2}$ & $\mathrm{SiO}_{2}$ & $\mathrm{Fe}_{2} \mathrm{O}_{3}$ & $\mathrm{Na}_{2} \mathrm{O}$ & $\mathrm{CaO}$ & $\mathrm{B}_{2} \mathrm{O}_{3}$ \\
\hline Alumina & 99.7 & - & 0.01 & 0.03 & 0.03 & 0.18 & 0.03 & - \\
Magnesia & 0.08 & 99.2 & - & 0.26 & 0.08 & - & 0.38 & 0.03 \\
\hline
\end{tabular}

Table 2 Compositions of experimental investments and water/powder ratio

\begin{tabular}{ccccc}
\hline & $\begin{array}{c}\mathrm{MgO} \text { content } \\
(\mathrm{mass} \%)\end{array}$ & $\begin{array}{c}\mathrm{Mol} \text { ratio of } \mathrm{MgO} \\
\text { to } \mathrm{Al}_{2} \mathrm{O}_{3}\end{array}$ & $\begin{array}{c}\text { Gypsum content } \\
\text { (mass\%) }\end{array}$ & $\begin{array}{c}\text { Water/powder } \\
\text { ratio }\end{array}$ \\
\hline 1 & 0.0 & $0: 1$ & 20 & 0.28 \\
2 & 6.1 & $1: 6$ & 20 & 0.28 \\
3 & 11.7 & $1: 3$ & 20 & 0.28 \\
4 & 16.3 & $1: 2$ & 20 & 0.28 \\
5 & 28.7 & $1: 1$ & 20 & 0.28 \\
\hline
\end{tabular}




\section{Setting time}

The Vicat needle penetration test was employed to measure the setting time; the diameter of the Vicat needle was $2 \mathrm{~mm}$ and its load was $3 \mathrm{~N}$. The freshly mixed investment was poured into a brass ring $(30 \mathrm{~mm}$ in diameter and $30 \mathrm{~mm}$ in length); the needle was allowed to penetrate the mix at 15 -second intervals until it would no longer do so. The setting time was recorded as the total time from the start of mixing to the time when the needle failed to make a perceptible circular indentation on the surface of the specimen. Three repetitions were done for each investment composition.

\section{Setting expansion}

Dimensional changes during setting were continuously measured up to 120 minutes after the start of mixing. The freshly mixed investment was put into a steel ring (35 $\mathrm{mm}$ in diameter and $45 \mathrm{~mm}$ in length) with two folds of a $0.7 \mathrm{~mm}$ ceramic liner (New casting Liner No.3, GC, Tokyo, Japan). A $17 \mathrm{~mm}$ diameter circular acrylic plate was placed on top of the investment. The movement of the acrylic plate was monitored by a dial gauge (Peacock 107, Ozakiseisaku, Tokyo, Japan); the measuring load was approximately $0.16 \mathrm{~g} / \mathrm{mm}^{2}$. The setting expansion 120 minutes after the start of mixing was calculated as the percentage expansion based on the smallest reading of the dial gauge during setting and the final length of the measured specimen. Three measurements were performed for each investment type.

\section{Compressive strength}

The freshly mixed investment was poured into a brass mold $(10 \mathrm{~mm}$ in diameter and $15 \mathrm{~mm}$ height). The set specimens were removed from the mold 55 minutes after the start of mixing except for the specimens of 11.7 mass $\% \mathrm{MgO}$ investment mixed with distilled water which were removed 115 minutes after the start of mixing. These specimens were kept in a container with a $100 \%$ relative humidity. Green strengths 2 hours after the start of mixing were obtained by the compressive test using a universal test machine (1123, Instron, Canton, MA, USA) with a crosshead speed of 0.5 $\mathrm{mm} / \mathrm{min}$. The fired strengths of the specimens were also obtained in the abovementioned manner after firing. The specimens were heated from 24 hours after the start of mixing to $1200^{\circ} \mathrm{C}$ at a rate of $10^{\circ} \mathrm{C} / \mathrm{min}$ and to $1400^{\circ} \mathrm{C}$ at a rate of $5{ }^{\circ} \mathrm{C} / \mathrm{min}$ using a SiC furnace (FG41, Yamato Engineering, Tokyo, Japan), then cooled to room temperature. Six specimens of each investment were tested.

\section{X-ray diffraction}

Cylindrical specimens of the investment with 11.7 mass $\% \mathrm{MgO}$ content mixed with $\mathrm{K}_{2} \mathrm{SO}_{4}$ fired at 1000,1200 and $1400^{\circ} \mathrm{C}$ as described previously ${ }^{3)}$ were crushed into powder for the measurement. Changes of crystal component before and after firing were measured by an X-ray diffraction analyzer (XRD; RAD-II A, Rigaku, Tokyo, Japan) with $\mathrm{CuK} \alpha$ radiation, a fixed divergence slit and a $2 \%$ min scanning speed. 


\section{Thermal analysis}

Thermal expansion was measured with a dilatometer (Dilatometer 5020, Mac Science, Tokyo, Japan). A cylindrical set investment (6 $\mathrm{mm}$ in diameter and $12 \mathrm{~mm}$ height) was heated in air from 2 hours after the start of mixing at a similar heating rate as that described for fired strength. Weight and endothermal/exothermal changes during heating and cooling of the set investment were analyzed using a TG-DTA (TGDTA 2000, Mac Science, Tokyo, Japan). A piece of each set investment was milled to a powder using a mortar and a pestle, then the powder was kept in a desiccator for at least 24 hours to remove physical water from the investment. Alumina powder was used as a standard; the examined mass of powder was $10.0 \mathrm{mg}$; the powder was heated to $1400^{\circ} \mathrm{C}$ at $10^{\circ} \mathrm{C} / \mathrm{min}$ and then cooled to room temperature at $10^{\circ} \mathrm{C} / \mathrm{min}$. Thermal analysis was performed three times for each investment.

\section{Casting}

An invar-steel mold was employed for fabrication of a trapezoidal wax pattern ${ }^{8)}$ (Fig. 1); the wax pattern was prepared using the mold with inserters. The dimensions of the wax patterns were $12.7 \mathrm{~mm}$ in the upper length, $14.0 \mathrm{~mm}$ in the lower length, 11.0 $\mathrm{mm}$ in height and $2.0 \mathrm{~mm}$ in thickness. Distances between the upper line of the wax pattern and the mold without the smaller inserter at three locations were measured using a profile projector (Model 6C, Nikon, Tokyo, Japan) and recorded as DW. A wax sprue $(2.5 \mathrm{~mm}$ in diameter) and a running bar $(4.0 \mathrm{~mm}$ in diameter and $10 \mathrm{~mm}$ in length) were attached to the wax pattern, the wax pattern was held at the center of a ceramic ring ( $42 \mathrm{~mm}$ in diameter and $55 \mathrm{~mm}$ in height) lined with one fold of a $2.0 \mathrm{~mm}$ ceramic liner (Ceramic liner Cyclarc, Morita, Kyoto, Japan). The alumina investment with 6.1 and 11.7 mass $\% \mathrm{MgO}$ content mixed with the 2 mass $\% \mathrm{~K}_{2} \mathrm{SO}_{4}$ solution was employed. The mold was heated at the same heating rate described for the fired strength, commencing 24 hours after the start of mixing. A titanium ingot

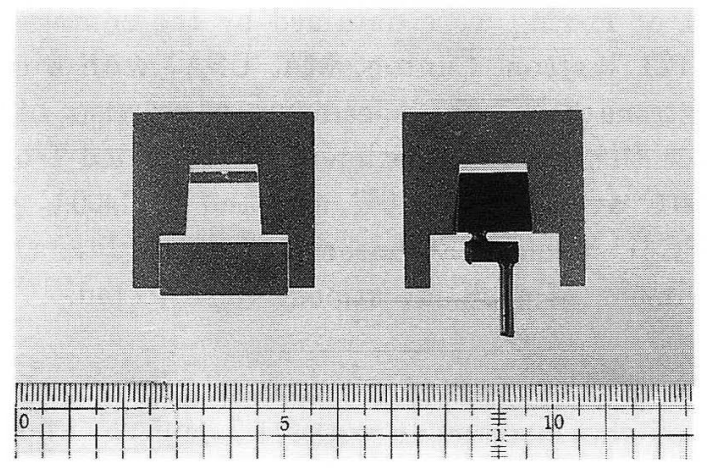

Fig. 1 Mold and wax pattern; the upper and lower lines of the wax pattern were 12.7 and $14.0 \mathrm{~mm}$, respectively; the height and thickness were 11.0 and 2.0 $\mathrm{mm}$, respectively. 
(Dental pure titanium A, $10 \mathrm{~g}$, Morita, Kyoto, Japan) was cast into the mold using an argon arc melting, gas pressure and centrifugal casting machine (Vulcan-T, Shofu, Kyoto, Japan). The dimensions of the casting after sandblasting using alumina powder (Pencil jet SM, Yoshida, Tokyo, Japan) were also measured by the same procedure as for the wax pattern, and recorded as DC. Dimensional accuracy of the casting (D) was calculated by the following formula based on the dimensions of the invar-steel mold:

$$
\mathrm{D}=\Delta \mathrm{d} \times[(14.0-12.7) /(11.0 \times 12.7)] \times 100
$$

where $\Delta d$ was the amount of dimensional discrepancy between DW $(\mathrm{mm})$ and DC $(\mathrm{mm})$.

The surfaces of the casting obtained from the 11.7 mass $\% \mathrm{MgO}$ content investment after sandblasting were analyzed using a electron probe micro analyser (EDX; Delta V, Kevex, Foster, CA, USA) for determining the contamination of the investment elements by the casting. The centers of the sprue, the running bar and the casting were measured three times.

\section{RESULTS}

\section{Fluidity magnesia}

The fluidity measurements are shown in Fig. 2. The error bars in the figure indicate the standard deviations. The fluidities of the investments ranged from 31.0 to 55.8 $\mathrm{mm}$. The fluidity of the investment without magnesia mixed with $\mathrm{K}_{2} \mathrm{SO}_{4}$ could be not measured because of the short setting time; however, that mixed with distilled water could be measured $(31.3 \mathrm{~mm})$. The fluidities of the investment increased with increasing of magnesia content. Fluidity of almost all investments showed a smaller value compared to the minimum limit of the JIS requirement ${ }^{7)}$ of $55 \mathrm{~mm}$; however, it was possible to use them as investment using a vibrator because of their thixotropicity.

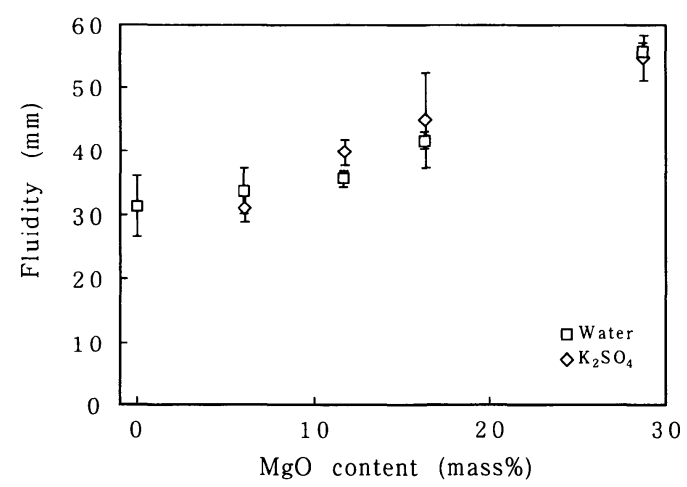

Fig. 2 Effect of magnesia content and potassium sulfate on fluidity.

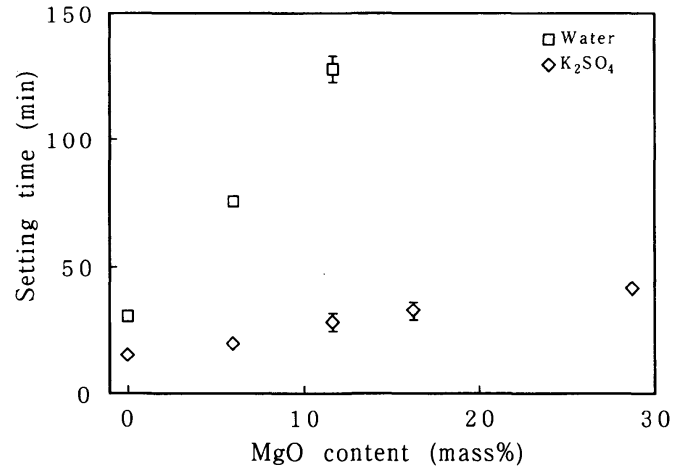

Fig. 3 Effect of magnesia content and potassium sulfate on setting time. 


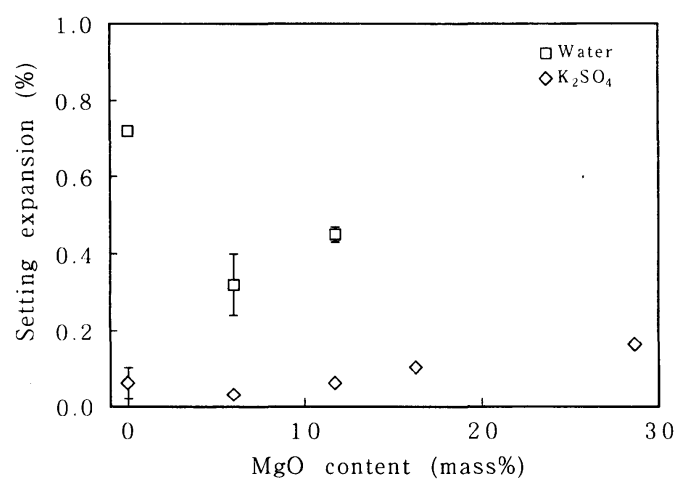

Fig. 4 Effect of magnesia content and potassium sulfate on setting expansion 2 hours after the start of mixing.

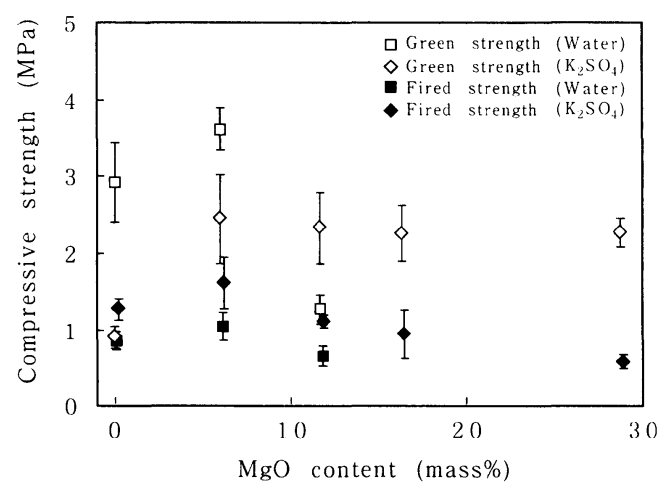

Fig. 5 Effect of magnesia content and potassium sulfate on green strength 2 hours after the start of mixing, and fired strength.

\section{Setting time}

The obtained setting times are indicated in Fig. 3. Increased $\mathrm{MgO}$ content of the investments had a tendency to delay the setting time. The investments with more than 11.7 mass \% $\mathrm{MgO}$ content did not set until 120 min when mixed with distilled water. The setting times significantly decreased when the investments were mixed with $\mathrm{K}_{2} \mathrm{SO}_{4}$.

\section{Setting expansion}

The setting expansion of the investments 120 minutes after the start of mixing is illustrated in Fig. 4. The setting expansions mixed with $\mathrm{K}_{2} \mathrm{SO}_{4}$ were significantly smaller than those mixed with distilled water. Increased magnesia content of the investments mixed with $\mathrm{K}_{2} \mathrm{SO}_{4}$ caused only a slight change of the setting expansion; however, when mixed with distilled water, a small amount of magnesia content decreased the setting expansion.

\section{Compressive strength}

Fig. 5 shows the green strengths 2 hours after the start of mixing, and the fired strengths of each investment. When mixed with distilled water, the green strength of 6.1 mass \% $\mathrm{MgO}$ content was larger than that without $\mathrm{MgO}$; however, the green strength of 11.7 mass \% $\mathrm{MgO}$ content decreased because the investment was not completely set when measured.

The fired strengths of the investments with $\mathrm{K}_{2} \mathrm{SO}_{4}$ showed a larger value than those mixed with distilled water. The 6.1 mass $\% \mathrm{MgO}$ content investment showed the largest fired strength, $1.61 \mathrm{MPa}$.

\section{$X$-ray diffractometer}

The X-ray diffraction patterns are shown in Fig.6. Strong diffraction lines of 


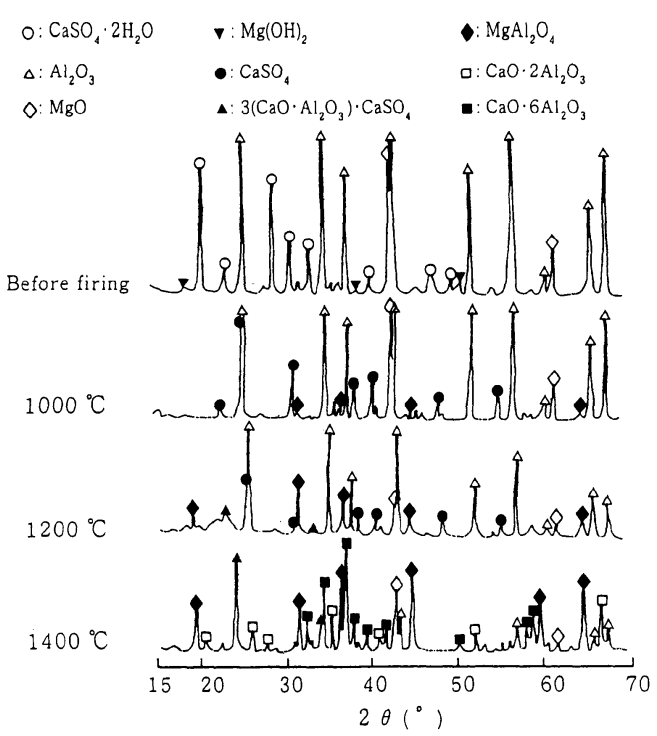

Fig. 6 X-ray diffraction pattern of the investment before and after firing Investment with 11.7 mass\% $\mathrm{MgO}$ content mixed with $\mathrm{K}_{2} \mathrm{SO}_{4}$.

$\mathrm{CaSO}_{4} \cdot 2 \mathrm{H}_{2} \mathrm{O}, \mathrm{MgO}, \mathrm{Mg}(\mathrm{OH})_{2}$ and $\mathrm{Al}_{2} \mathrm{O}_{3}$ were observed from the powder before firing; diffraction lines of $\mathrm{CaSO}_{4}$ instead of $\mathrm{CaSO}_{4} \cdot 2 \mathrm{H}_{2} \mathrm{O}$ and $\mathrm{MgAl}_{2} \mathrm{O}_{4}$ were found from the powder after $1000^{\circ} \mathrm{C}$ firing; diffraction lines of $3\left(\mathrm{CaO} \cdot \mathrm{Al}_{2} \mathrm{O}_{3}\right) \cdot \mathrm{CaSO}_{4}$ appeared from the powder after $1200^{\circ} \mathrm{C}$ firing; diffraction lines of $\mathrm{CaO} \cdot 2 \mathrm{Al}_{2} \mathrm{O}_{3}$ and $\mathrm{CaO} \cdot 6 \mathrm{Al}_{2} \mathrm{O}_{3}$ were also observed from the powder after $1400^{\circ} \mathrm{C}$ firing. The final crystal components after $1400^{\circ} \mathrm{C}$ firing were considered to be $\mathrm{MgAl}_{2} \mathrm{O}_{4}, \mathrm{Al}_{2} \mathrm{O}_{3}, 3\left(\mathrm{CaO} \cdot \mathrm{Al}_{2} \mathrm{O}_{3}\right) \cdot \mathrm{CaSO}_{4}$, $\mathrm{CaO} \cdot 2 \mathrm{Al}_{2} \mathrm{O}_{3}$ and $\mathrm{CaO} \cdot 6 \mathrm{Al}_{2} \mathrm{O}_{3}$.

\section{Thermal analysis}

Figs. 7A-B show the typical thermal dimensional changes of the investments. Thermal contractions between $350-450^{\circ} \mathrm{C}$ were detected in all investments; those between $900-$ $1150^{\circ} \mathrm{C}$ were also observed in almost all investments; thermal expansion between 1200 $1400^{\circ} \mathrm{C}$ and thermal linear contractions during cooling were observed in all investments. These behaviors are consistent with the previous report ${ }^{3)}$. When the investments were mixed with $\mathrm{K}_{2} \mathrm{SO}_{4}$, the thermal contraction at $900-1150^{\circ} \mathrm{C}$ was smaller and the thermal expansion at $1200-1400^{\circ} \mathrm{C}$ was more rapid and larger. When the $\mathrm{MgO}$ content increased, the thermal contraction at $900-1150^{\circ} \mathrm{C}$ increased, however, the thermal contraction between $900-1150^{\circ} \mathrm{C}$ of the investment with 11.7 mass $\% \mathrm{MgO}$ content was the smallest $(0.00 \%)$; the thermal expansion at $1200-1400^{\circ} \mathrm{C}$ also increased, especially when the $\mathrm{MgO}$ content was 11.7 mass\%; the residual expansions of magnesia content at $0.0,6.1,11,7,16.3$ and 28.7 mass $\%$ were $1.81 \%, 2.36 \%, 2.48 \%, 1.54 \%$ and $0.77 \%$, 

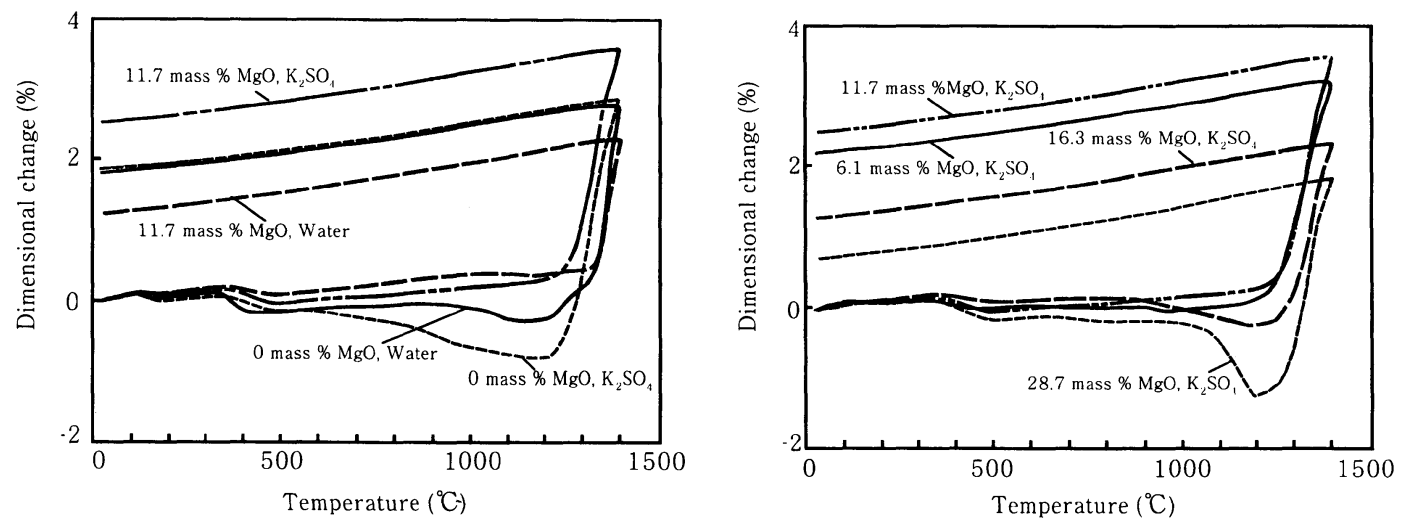

Fig. 7 Typical thermal expansion curves.

A: effect of potassium sulfate

B: effect of magnesia content

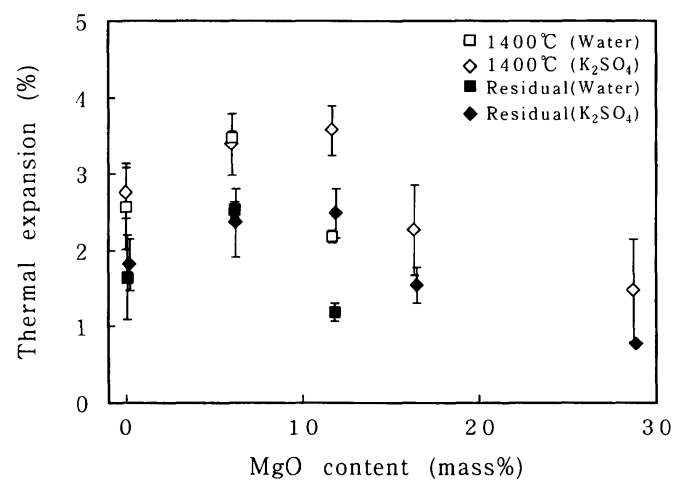

Fig. 8 Effect of magnesia content and potassium sulfate on thermal expansion at $1400^{\circ} \mathrm{C}$ and residual expansion after cooling to room temperature.

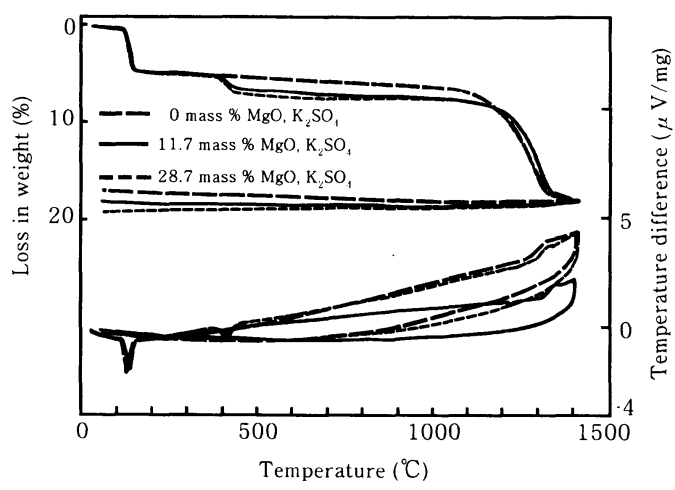

Fig. 9 Typical TG-DTA curves.

respectively (Fig. 8).

Typical TG-DTA diagrams of the investments are illustrated in Fig. 9. When the $\mathrm{MgO}$ content was identical, there was no obvious difference except for weight loss at $400^{\circ} \mathrm{C}$ between the TG-DTA diagrams of the investments mixed with distilled water and those mixed with $\mathrm{K}_{2} \mathrm{SO}_{4}$. An endothermic peak with weight loss due to dehydration of $\mathrm{CaSO}_{4} \cdot 2 \mathrm{H}_{2} \mathrm{O}_{4}$ was observed between $100-130^{\circ} \mathrm{C}$; a small exothermic peak without weight loss due to transformation from III $\mathrm{CaSO}_{4}$ to II $\mathrm{CaSO}_{4}$ was observed at approximately $350^{\circ} \mathrm{C}$; an endothermic peak with weight loss at $400^{\circ} \mathrm{C}$ because of $\mathrm{Mg}(\mathrm{OH})_{2}$ dehydration ${ }^{9)}$ was observed when the investment contained $\mathrm{MgO}$ mixed with $\mathrm{K}_{2} \mathrm{SO}_{4}$; a broad endothermic peak with weight lost due to decomposition of $\mathrm{CaSO}_{4}$ was seen from approximately $900^{\circ} \mathrm{C}$; an small endothermic peak without obvious weight 


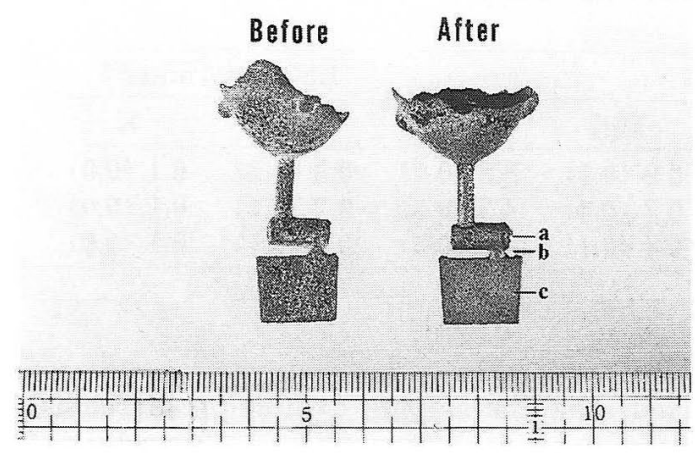

Fig. 10 Titanium casting obtained from investment before and after sandblasting (11.7 mass\% MgO content).

The element analysis was performed at the points indicated by arrows.

a: running bar, b: sprue, c: casting.

loss was recognized at $1220^{\circ} \mathrm{C}$; and a gradient weight loss and endothermic peak were observed until $1400^{\circ} \mathrm{C}$, there were no obvious endo/exothermic peaks and weight loss during cooling to room temperature. The amount of weight loss of the investment mixed with $\mathrm{K}_{2} \mathrm{SO}_{4}$ before firing to $200^{\circ} \mathrm{C}$ and that before firing from $600^{\circ} \mathrm{C}$ to $1400^{\circ} \mathrm{C}$ were 4.4-4.7 and 9.7-11.4\%, respectively, regardless of the amount of $\mathrm{MgO}$ content; however, the amount of weight loss of the investment mixed with $\mathrm{K}_{2} \mathrm{SO}_{4}$ at $400^{\circ} \mathrm{C}$ increased with increasing $\mathrm{MgO}$ content: the means and standard deviations of weight loss before firing 200 to $600^{\circ} \mathrm{C}$ at $0.0,6.1,11.7,16.3$ and 28.7 mass \% magnesia content were $0.0 \pm 0.0 \%, 0.5 \pm 0.1 \%, 1.8 \pm 0.3 \%, 2.1 \pm 0.2 \%$ and $2.2 \pm 0.1 \%$, respectively.

\section{Casting}

The obtained casting is shown in Fig. 10. Almost all investments were easily removed from the casting without sandblasting. After sandblasting, a metallic surface was easily obtained. Small casting fins were observed on the upper line of one half of the castings. The EDX analysis revealed contamination of $\mathrm{Al}, \mathrm{Mg}, \mathrm{S}, \mathrm{Ca}$ and $\mathrm{K}$ on the titanium casting (Table 3). The amount of contamination was the largest at the running bar; however, contamination was the smallest at the center of the casting. The obtained castings were larger than their wax patterns. Dimensional accuracy of castings obtained from 6.1 and 11.7 mass \% magnesia content were $0.01 \pm 0.09 \%$ and 0.23 $\pm 0.10 \%$, respectively.

\section{DISCUSSION}

The water/powder ratio used in this study (0.28) was smaller than that in the previous report $\mathrm{t}^{3)}(0.31)$ in an effort to reduce setting time; as a result, the setting time 
Table 3 Results of elemental analysis of the surface of the titanium casting after sandblasting

\begin{tabular}{lccccccc}
\hline \multirow{2}{*}{ Sampling part } & \multicolumn{7}{c}{ Element $($ mass\%) } \\
\cline { 2 - 8 } & $\mathrm{Mg}$ & $\mathrm{Al}$ & $\mathrm{S}$ & $\mathrm{K}$ & $\mathrm{Ca}$ & $\mathrm{Ti}$ \\
\hline Running bar & $0.9(0.1)$ & $8.5(0.7)$ & $0.3(0.2)$ & $0.1(0.0)$ & $0.3(0.1)$ & $90.1(0.8)$ \\
Sprue & $0.7(0.4)$ & $4.3(0.5)$ & $0.2(0.1)$ & $0.1(0.0)$ & $0.4(0.2)$ & $94.3(0.6)$ \\
Center & $0.4(0.1)$ & $4.5(0.5)$ & $0.2(0.1)$ & $0.1(0.0)$ & $0.3(0.1)$ & $94.5(0.5)$ \\
\hline
\end{tabular}

and the fluidity decreased, and the setting expansion increased compared with the investments of identical composition in the previous report. Potassium sulfate accelerates the setting of gypsum; however, the effect of magnesia on gypsum setting have not been clearly confirmed. XRD and TG-DTA analysis revealed that some amount of magnesia in the investment hydrated to magnesium dihydrate after setting. Magnesium dihydrate is reported to be an accelerator ${ }^{6)}$, however, magnesia acted as a retarder of setting with respect to fluidity and setting time in this study.

Potassium sulfate and magnesia are also known to reduce the setting expansion and green strength of gypsum ${ }^{6,10)}$. The experimental investment used in this study consisted of gypsum and alumina: the alumina powder increased the setting expansion and decreased green strength of the gypsum ${ }^{3)}$. When mixed with distilled water, the green strength of 6.1 mass $\% \mathrm{MgO}$ content was larger than that without $\mathrm{MgO}$; however, that of 11.7 mass \% $\mathrm{MgO}$ content decreased because, the investment was not completely set 2 hours after the start of mixing. The means and standard deviations of green strength 4 hours after the start of mixing of $0,6.1$ and 11.7 mass $\% \mathrm{MgO}$ content investments mixed with distilled water were $2.64 \pm 0.43 \mathrm{MPa}, 3.06 \pm 0.18 \mathrm{MPa}$, and $3.23 \pm 0.27 \mathrm{MPa}$, respectively. After setting, the investments with $\mathrm{MgO}$ mixed with distilled water slightly increased and did not change with respect to $\mathrm{MgO}$ content. Mixing with potassium sulfate decreased the green strengths of the investments, while magnesia increased the green strengths of the investments; nevertheless the green strengths of the investments were lower than that of gypsum. Fig. 11 shows SEM images of the experimental investment structures after setting. The calcium sulfate dihydrate crystals of the $\mathrm{MgO}$ content investment mixed with distilled water (Fig. 11b) were larger than those in the investment without $\mathrm{MgO}$ (Fig. 11a), while those of the investment without $\mathrm{MgO}$ mixed with $\mathrm{K}_{2} \mathrm{SO}_{4}$ (Fig. 11c) were smaller than those of the investment mixed with distilled water (Fig. 11a). Such variation in crystal size had an influence on the setting behavior of the investment. However, it was advantageous that the green strength of the investment mixed with potassium sulfate increased when the investment contained magnesia.

In this study, the experimental investment were fired at $1400^{\circ} \mathrm{C}$. As a result, the fired strengths of the investment were similar to those of recent commercial gypsumbonded investments because of sintering of some components.

The thermal behavior of the investment was consistent with the previous report $^{3)}$ except for the dehydration of $\mathrm{Mg}(\mathrm{OH})_{2}$ and the formation of alumina- 

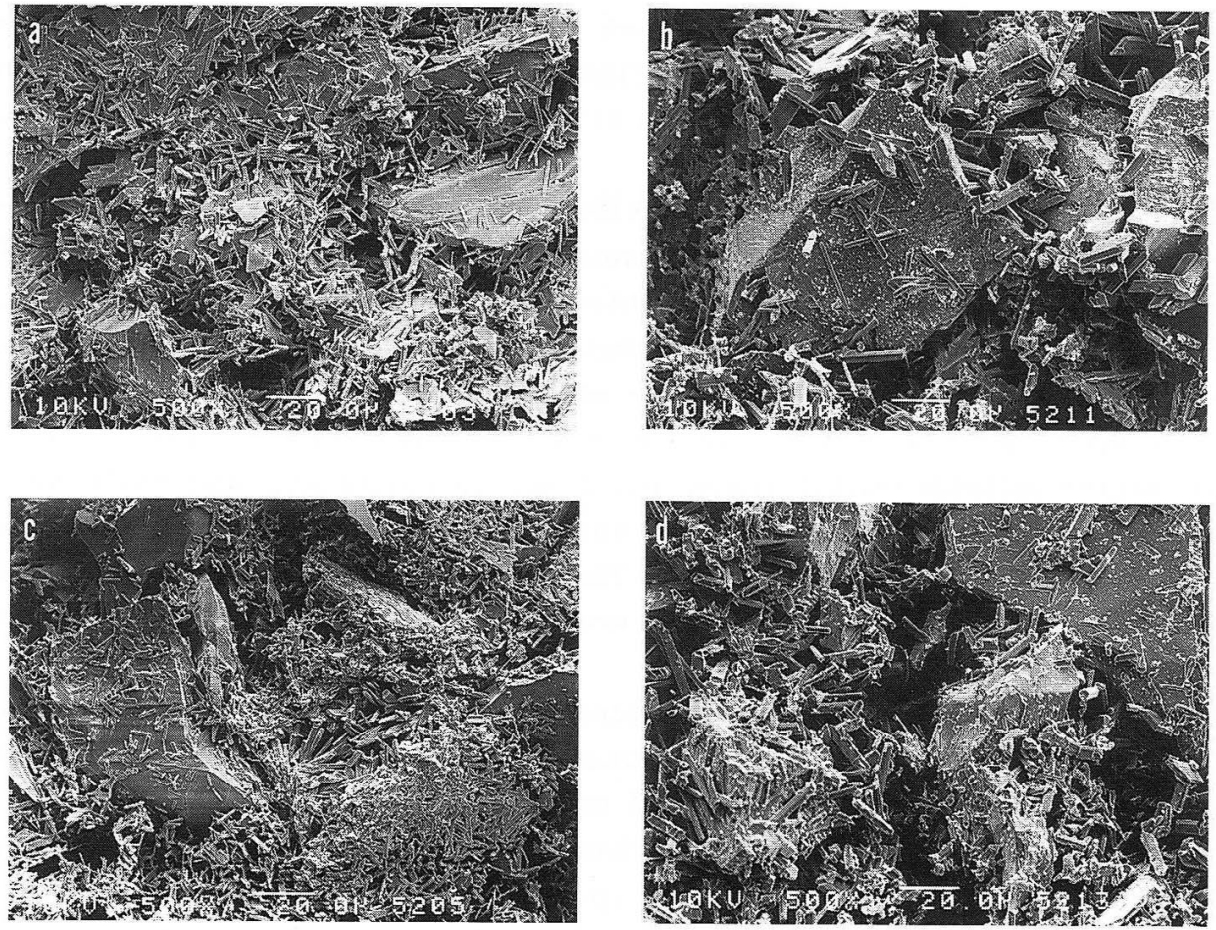

Fig. 11 SEM images of experimental investments structure after settting. a: 0 mass \% $\mathrm{MgO}$ content investment mixed with distilled water b: 6.1 mass \% $\mathrm{MgO}$ content investment mixed with distilled water c: 0 mass\% $\mathrm{MgO}$ content investment mixed with $\mathrm{K}_{2} \mathrm{SO}_{4}$ d: 6.1 mass \% $\mathrm{MgO}$ content investment mixed with $\mathrm{K}_{2} \mathrm{SO}_{4}$

magnesia spinel $\left(\mathrm{MgAl}_{2} \mathrm{O}_{4}\right)$. When all magnesia in the investment was hydrated, the theoretical weight losses of $\mathrm{Mg}(\mathrm{OH})_{2}$ to $\mathrm{MgO}$ for the investments with 6.1, 11.7, 16.3 and 28.7 mass $\% \mathrm{MgO}$ content were $0.0 \%, 2.2 \%, 4.2 \%, 5.9 \%$ and $10.1 \%$, respectively. The observed weight losses due to $\mathrm{Mg}(\mathrm{OH})_{2}$ dehydration were almost one third to one fifth of the theoretical values. These results suggested that not all magnesia hydrated after setting. This hydration ratio was smaller when the investment was mixed with distilled water. We conclude that potassium sulfate acted as an accelerator for magnesia hydration in this study.

The thermal expansion at $1200-1400{ }^{\circ} \mathrm{C}$ depended on the formation of $3(\mathrm{CaO}$. $\left.\mathrm{Al}_{2} \mathrm{O}_{3}\right) \cdot \mathrm{CaSO}_{4}, \mathrm{CaO} \cdot 6 \mathrm{Al}_{2} \mathrm{O}_{3}, \mathrm{CaO} \cdot 2 \mathrm{Al}_{2} \mathrm{O}_{3}$ and $\mathrm{MgAl}_{2} \mathrm{O}_{4}$. The theoretical expansions due to formation of $3\left(\mathrm{CaO} \cdot \mathrm{Al}_{2} \mathrm{O}_{3}\right) \cdot \mathrm{CaSO}_{4}, \mathrm{CaO} \cdot 6 \mathrm{Al}_{2} \mathrm{O}_{3}$ and $\mathrm{MgAl}_{2} \mathrm{O}_{4}$ were $35.9 \%$, $3.8 \%$ and $8.1 \%$, respectively. Addition of a small amount of $\mathrm{MgO}$ content to the gypsum-bonded alumina investment was effective in increasing the thermal expansion because of $\mathrm{MgAl}_{2} \mathrm{O}_{4}$ formation, however, large amounts of $\mathrm{MgO}$ were not so effective. This might be due to the reduction of alumina content in the investment. When the investment was mixed with $\mathrm{K}_{2} \mathrm{SO}_{4}$, its investment showed a small setting expansion; 
therefore, the refractory particle $\left(\mathrm{MgO}\right.$ and $\left.\mathrm{Al}_{2} \mathrm{O}_{3}\right)$ packed tightly by the gypsum and had a large contact surface area to the gypsum. These phenomena might be responsible for reducing the thermal contraction at $900-1150^{\circ} \mathrm{C}$ and increasing the thermal expansion $1200-1400^{\circ} \mathrm{C}$.

The following effects of potassium sulfate and magnesia on the gypsum-bonded alumina investment became clear after examining the experimental results. Mixing the investment with potassium sulfate solution accelerated the setting reaction but decreased setting expansion and green strength. Magnesia content of the investment improved fluidity and retarded the setting reaction, but increased the green strength. Especially when mixed with $\mathrm{K}_{2} \mathrm{SO}_{4}$, the investments with small amounts of magnesia content showed suitable setting times, small setting expansion, and sufficient green strength. It was possible to control the amount of thermal expansion by adjusting the magnesia content of the investment. Therefore, the investments with 6.1 and 11.7 mass $\% \mathrm{MgO}$ content mixed with $\mathrm{K}_{2} \mathrm{SO}_{4}$ were employed for evaluating the titanium casting.

It was possible to fabricate a titanium casting using this experimental investment. The investment was completely removed from the casting surface with sandblasting. Small casting fins were found on the upper line of some castings. The green and fired strengths of the investments used for titanium casting were smaller than phosphate-bonded investments ${ }^{11)}$ or special investments for titanium casting ${ }^{12)}$. The casting pressure of the casting machine used was relatively large, which may have been the cause of the casting fins. The EDX revealed contamination by $\mathrm{Al}, \mathrm{Mg}$, $\mathrm{S}$, $\mathrm{Ca}$ and $\mathrm{K}$ from the casting, however, the amount of the contamination was small. The surface of the titanium casting was rough, and it would be necessary to modify the particle distribution of the refractory to obtain a smooth cast surface.

The setting expansion and residual thermal expansion values of the investments with 6.1 and 11.7 mass $\% \mathrm{MgO}$ content investment were 0.03 and $2.36 \%$ and 0.06 and $2.48 \%$, respectively. The total expansion of these investments was estimated to be 2.39 and $2.54 \%$; therefore, the casting shrinkage of a titanium was calculated 2.38 and $2.31 \%$. This casting shrinkage of titanium was larger than the previous report of $1.8-2.0 \%{ }^{13,14)}$. These discrepancies were considered to be due to differences in the casting conditions.

\section{CONCLUSION}

In this study, the effects of magnesia and potassium sulfate on the gypsum-bonded alumina investment were investigated. Magnesia content improved the fluidity, delayed the setting reaction, and increased the green strength, and decreased the setting expansion of the investment mixed with distilled water. When the investment was mixed with potassium sulfate, the setting time and setting expansion were reduced, and the thermal expansion increased, however, the green strength decreased. Therefore, the investment with small amount of magnesia content mixed with potassium sulfate was considered a suitable composition, having adequate setting behavior, 
enough green strength and sufficient compensate expansion for casting. A titanium casting was obtained using the investment and contamination by investment components of the casting surface was minimal.

\section{ACKNOWLEDGMENTS}

The authors would like to express their appreciation to professor Fumio Nishimura of the Department of Dental Technology I at Tokyo Medical and Dental University for his valuable guidance and help throughout his research. We also thank Dr. Hideo Nakamura, Dr. Kazuo Motomura and Mr. Naohiko Iwasaki of the same department for preparing the manuscript.

We would like to extend our gratitude to GC Corp., Japan, for providing the gypsum.

\section{REFERENCES}

1) Anusavice, K. J.: Phillips' science of dental materials, 10th ed., W. B. Saunders. Co., Philadelphia, 1996, pp.69-490.

2) Sasaki, T.: Study on refractory materials of gypsum-bonded investments, $J J$ Dent Mater 10(2) : 219-240, 1991. (in Japanese)

3) Yan, M. and Takahashi, H.: Gypsum-bonded alumina dental investment for high-fusing casting, Dent Mater J 17(3): 174-185, 1998.

4) Tokunaga, K.: Application of magnesia clinker to dental casting investments, $J$ Japan Res Soc Dent Mat Appl 34(3): 205-220, 1977. (in Japanese)

5) Oda, Y.: Some feature of titanium casting systems, $D E 111: 11-20,1994$. (in Japanese)

6) Sekitani, M.: Gypsum, Kasai Press, Tokyo, 1964, pp.208-237. (in Japanese)

7) JIS T 6601-1989 Gypsum-bonded dental investments for casting.

8) Habu, N.: study of reduction of dental casting time using quick heating gypsum-bonded investment mixed with accelerator solution, $J J$ Dent Mater 17(1) :76-88, 1998. (in Japanese)

9) Hayashi, T.: Basic refractory, Casting techniques editorial board: Nenryo taikabutsu (Fuel and refractory), Nikkan Kougyou Shinbunsya, Tokyo, 1969, pp.219-225. (in Japanese)

10) Hiyama, S. and Fukui, H.: Expansion of gypsum by adding material, Gypsum 2:27-37, 1951. (in Japanese)

11) Yan, M., Takahashi, H., Nishimura, F., Habu, N., Nakamura, H. and Motomura, K.: Comparison of properties of phosphate-bonded investments for quick heating, $J J$ Dent Mater 16(5) : 405-414, 1997. (in Japanese)

12) Ohtani, T., Nakano, F., Habu, N., Yan, M., Iwasaki, N., Motomura, K., Nakamura, H., Takahashi, H., Nishimura, F. and Ishiwata, M.: Studies of short-time cast for titanium (Part 1) properties of dental investments for titanium with quick heating, Society for titanium alloys in dentistry 10th :68-69, 1997. (in Japanese)

13) Takahashi, H., Miyazaki, T. and Kawawa, T.: Accuracy of titanium casting crowns obtained from calcia base mold, Clinical Materials 16:155-160, 1994.

14) Nishimura, F., Watari, F., Nakamura, H., Fukumoto, R. and Morita, N.: Casting accuracy and shrinkage of titanium castings made with zirconia investment, $J J$ Dent Mater 9(6) : 850-857, 1990. (in Japanese) 